Electronic Supporting Information for

\title{
Aluminum Metal-Organic Framework Triggers Carbon Dioxide Reduction Activity
}

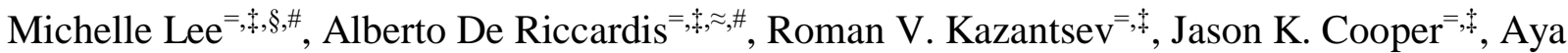

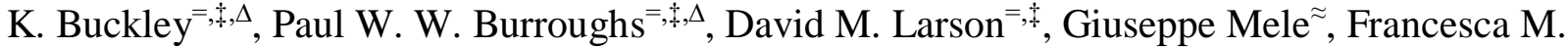
Toma $=,+, *$

=Joint Center for Artificial Photosynthesis, Lawrence Berkeley National Laboratory, 1 Cyclotron Road, Berkeley, CA 94720, USA.

"Chemical Sciences Division, Lawrence Berkeley National Laboratory, 1 Cyclotron Road, Berkeley, CA 94720, USA.

${ }^{\S}$ Department of Chemistry and Chemical Biology, Cornell University, Ithaca, NY 14853, USA.

चDepartment of Engineering for Innovation, University of Salento, via Arnesano, 73100 Lecce LE, Italy.

${ }^{\Delta}$ Department of Chemistry, University of California, Berkeley, CA 94720, USA.

${ }^{\#}$ M.L and A.D.R contributed equally to this work.

*email: fmtoma@lbl.gov

Material and Methods

Reference 


\section{Materials and Methods}

Chemicals: Anhydrous N,N-Dimethylformamide (DMF) (99.8\%), nitric acid (70\%), aluminum chloride hexahydrates $\left(\mathrm{AlCl}_{3} \cdot 6 \mathrm{H}_{2} \mathrm{O}\right)(99 \%)$, terephthalic acid (98\%), Nafion 117 solution, 2,2,2-trifluoroethanol, and high purity potassium carbonate (99.995\%) were purchased from Sigma Aldrich. Hydrochloric acid (36.5 - 38\%) was purchased from VWR. Isopropyl alcohol $(100 \%)$ was purchased from KMG electronic chemicals. Water used for all of the synthesis and electrochemical experiments (MilliQ water) was from a Milli-Q Water Purification System (resistivity of 18.2 M $\Omega$-cm, Millipore). Selemion AMV anion-exchange membrane was purchased from AGC Engineering Co., LTD. Carbon paper (Sigracet 29BC) was purchased from Fuel Cell Store. Carbon dioxide (99.995\%) and nitrogen (99.999\%) were obtained from Praxair.

\section{MIL-53(Al) Synthesis:}

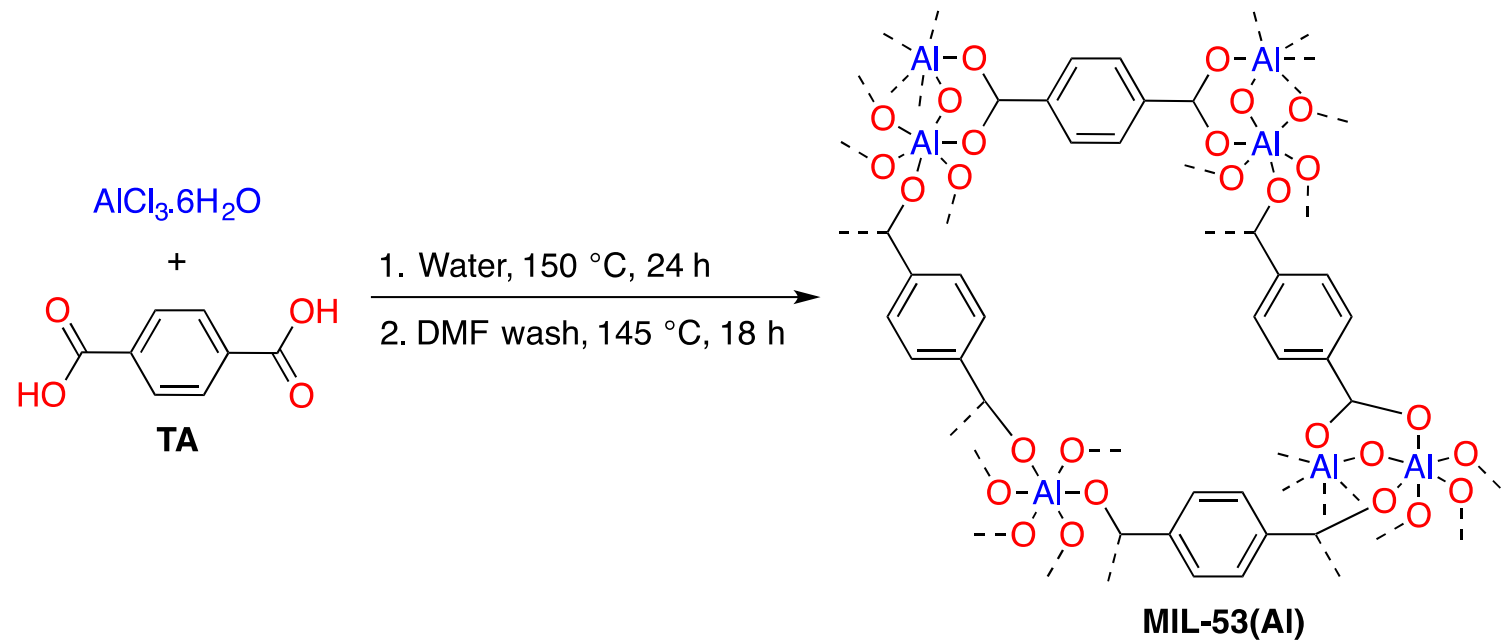

MIL-53(Al) was synthesized with a slightly modified procedure already present in the literature ${ }^{1}$. In a fume hood, a $22 \mathrm{~mL}$ Teflon reactor was charged with $\mathrm{AlCl}_{3} \cdot 6 \mathrm{H}_{2} \mathrm{O}(1.97 \mathrm{~g}, 8 \mathrm{mmol})$. $20 \mathrm{~mL}$ of MilliQ water were carefully added. After all the $\mathrm{HCl}$ evolved from the hydrolysis was removed, terephthalic acid (TA, $1.38 \mathrm{~g}, 8 \mathrm{mmol}$ ) was added. The Teflon reactor was sealed and 
placed in a stainless steel autoclave reactor. The reactor was heated in a preheated oven $\left(150{ }^{\circ} \mathrm{C}\right)$ for 24 hours. The reactor was then allowed to cool down to room temperature before filtering the reaction mixture to obtain a white gel via Buchner filtration. The white gel was added into a 50 mL centrifuge tube. MilliQ water $(\sim 30 \mathrm{~mL})$ was added into the centrifuge tube. It was centrifuged for 20 minutes (Eppendorf centrifuge 5804). The supernatant was disposed to remove the unreacted $\mathrm{AlCl}_{3}$. The white gel was washed again several times using this centrifuge method. The washed white gel was briefly dried in a preheated BINDER oven $\left(90^{\circ} \mathrm{C}\right)$ for 1 hour before it was suspended in DMF $(\sim 15 \mathrm{~mL})$ in a $22 \mathrm{~mL}$ Teflon reactor. The Teflon reactor was sealed and placed in a stainless steel autoclave reactor. The reactor was put in preheated sand bath $\left(145^{\circ} \mathrm{C}\right)$ for 18 hours to remove any unreacted TA that may be trapped in the porous cavity of the MOF. ${ }^{2}$ The reactor was then allowed to cool down to room temperature before filtering the reaction mixture to obtain a white solid via Buchner filtration. The white solid was washed several times with isopropyl alcohol (IPA) by centrifugation to replace DMF that may be coordinated to the MOF. The supernatant was removed, leaving a white solid. The white solid was dried in a Lindberg Blue $\mathrm{M}$ vacuum oven from Thermo Fisher Scientific at $140{ }^{\circ} \mathrm{C}$ and $10 \mathrm{mmHg}$ for 18 hours to remove the remaining DMF and IPA.

Preparation of Carbon Paper: Carbon paper (Sigracet 29BC) was cut into $\sim 1.3 \mathrm{~cm} \mathrm{x} \sim 1.3$ $\mathrm{cm}$ squares. The cut carbon paper was immersed in $70 \%$ nitric acid for 15 minutes to remove metallic impurities that may be present in the fibers. ${ }^{6}$ The carbon paper was then washed with MilliQ water and air-dried for 18 hours.

Preparation of MIL-53(Al) Suspension: In a fume hood, a $20 \mathrm{~mL}$ scintillation vial was charged with MIL-53(Al) $(30 \mathrm{mg}, 0.036 \mathrm{mmol})$. MilliQ water $(3.8 \mathrm{~mL})$ and IPA $(1.0 \mathrm{~mL})$ were added. Nafion 117 solution $(40 \mu \mathrm{L})$ was added. The vial was sealed and sonicated for 30 minutes 
at room temperature to make a homogeneous suspension. The suspension $(40 \mu \mathrm{L})$ and trifluoroethanol $(40 \mu \mathrm{L})$ were added to a $2.0 \mathrm{~mL}$ microcentrifuge tube. Trifluoroethanol was added to allow the MIL-53(Al) suspension to permeate inside the fiber of carbon paper, which is coated with Teflon and highly hydrophobic. ${ }^{3}$ The microcentrifuge tube was vortexed for 30 seconds to make the final MIL-53( $\mathrm{Al})$ suspension homogeneous.

Preparation of $\mathrm{Al}(\mathrm{OH})_{3}$ Suspension: In a fume hood, a $20 \mathrm{~mL}$ scintillation vial was charged with $\mathrm{Al}(\mathrm{OH})_{3}(30 \mathrm{mg}, 0.38 \mathrm{mmol})$. MilliQ water $(3.8 \mathrm{~mL})$ and IPA (1.0 mL) were added. Nafion 117 solution $(40 \mu \mathrm{L})$ was added. The vial was sealed and sonicated for 30 minutes at room temperature to make a homogeneous suspension. The suspension $(40 \mu \mathrm{L})$ and trifluoroethanol (40 $\mu \mathrm{L}$ ) were added to a $2.0 \mathrm{~mL}$ microcentrifuge tube. Trifluoroethanol was added to allow the $\mathrm{Al}(\mathrm{OH})_{3}$ suspension to permeate inside the fiber of carbon paper, which is coated with Teflon and highly hydrophobic. ${ }^{3}$ The microcentrifuge tube was vortexed for 30 seconds to make the final $\mathrm{Al}(\mathrm{OH})_{3}$ suspension homogeneous.

Preparation of Fabricated Working Electrodes: The final suspension $(40 \mu \mathrm{L}, 0.124 \mathrm{mg}$ of powder) was deposited onto the prepared carbon paper electrodes. The electrode was then dried in a preheated BINDER oven $\left(90^{\circ} \mathrm{C}\right)$ for 18 hours. The back of the electrode was insulated with electroplating tape. The front was contacted with a piece of copper tape, and then covered with a second piece of electroplating tape with a round hole with diameter $\sim 1.26 \mathrm{~cm}$. This configuration would insulate the $\mathrm{Cu}$ tape as well as provide a precise exposed area of $1.25 \mathrm{~cm}^{2}$.

Electrolyte preparation: Potassium carbonate solution $(0.05 \mathrm{M})$ was prepared from high purity potassium carbonate (99.995\%, Sigma Aldrich) and water from a Milli-Q Water Purification System (resistivity of 18.2 M $\Omega$-cm, Millipore). 
Product detection: Electrochemical experiments were conducted in a two-compartment flow cell fabricated from PEEK following a reported design (Figure S1). ${ }^{4}$ A Selemion AMV anionexchange membrane separated the two chambers. A Pt foil was used as the counter electrode. A Leak-Free $\mathrm{Ag} / \mathrm{AgCl}$ electrode (LF-1, $1.0 \mathrm{~mm}$ outer diameter, Innovative Instruments, Inc.) was used as the reference electrode. The reference electrode was calibrated against a second reference electrode, which in turn was calibrated in a two-electrode system with $\mathrm{H}_{2}$ bubbled over a Pt wire as the counter electrode and a $1 \mathrm{M} \mathrm{H}_{2} \mathrm{SO}_{4}$ solution as the electrolyte. The applied potentials were converted from $\mathrm{Ag} / \mathrm{AgCl}$ scale to the $\mathrm{RHE}$ scale via the equation: $\mathrm{E}_{\mathrm{RHE}}=\mathrm{E}_{\mathrm{Ag} / \mathrm{AgCl}}+0.197+$ 0.059* $\mathrm{pH}$, where the $\mathrm{pH}$ used is the bulk $\mathrm{pH}$ for the $\mathrm{CO}_{2}$-saturated electrolyte (6.8). In the electrochemical cell, the prepared $0.05 \mathrm{M}$ potassium carbonate solution was used as electrolyte. The electrolyte was saturated with a continuous flow of $5 \mathrm{sccm} \mathrm{CO}_{2}$ for a minimum of 30 minutes within the experimental cell setup immediately prior to all electrochemical experiments. One cycle of chronoamperometric (CA) measurement was performed by applying a constant potential for 45 minutes. One cycle of $\mathrm{CA}$ at $-1.5 \mathrm{~V}$ vs $\mathrm{Ag} / \mathrm{AgCl}$ was performed before data collection was started. Electrochemical experiments were carried out using SP-200 potentiostat from BioLogic. Cyclic voltammetry (CV) was then performed and repeated at the end of each run in order to test the stability of material before and after the chronoamperometric measurement. Chronoamperometric measurement was performed for about 45 minutes. Gas products were quantified using gas chromatography (GC), Agilent Technologies 490 Micro GC (Shimadzu 490GC), through a flow mode. Liquid products were quantified after electrochemical measurement using high performance liquid chromatography (HPLC), UltiMate 3000. During the chronoamperometric measurement, gas from the cell was directed through the sampling loop of a gas chromatograph with molecular sieves columns (MOL 5A-Agilent) and was analyzed in 15 minutes intervals. For each interval, 
concentration of gas produced was collected. With total current density measured at the end of experiment and applied potential, faradaic efficiency for each gas for each interval was calculated. These recorded faradaic efficiencies were averaged and reported.

Characterization techniques: Powder X-ray diffraction (PXRD) patterns were acquired with a Rigaku-SmartLab diffractometer using $\mathrm{Cu} \mathrm{K} \alpha(\lambda=0.15406 \mathrm{~nm})$.

Scanning electron microscopy images of synthesized MIL-53(Al) were acquired with a FEI Quanta FEG250. In addition, scanning electron microscopy images of $\mathrm{Al}(\mathrm{OH})_{3}$ electrodes before and after electrochemical testing were acquired with a Zeiss Gemini Supra 55 VP-SEM.

X-ray Photoelectron Spectroscopy (XPS) was performed using a monochromatized Al Ka source $(\mathrm{h} v=1486.6 \mathrm{eV})$, operated at $225 \mathrm{~W}$, on a Kratos Axis Ultra DLD system at a takeoff angle of $0^{\circ}$ relative to the surface normal and a pass energy for the narrow scan core level and valence band spectra of $20 \mathrm{eV}$ to observe the electronic state of the elements within the material. Spectral fitting was conducted using Casa XPS analysis software. Spectral positions were corrected using adventitious carbon by shifting the $\mathrm{C} 1 s$ core level position to $284.8 \mathrm{eV}$ and curves were fit with quasi-Voigt lines following Shirley background subtraction. 


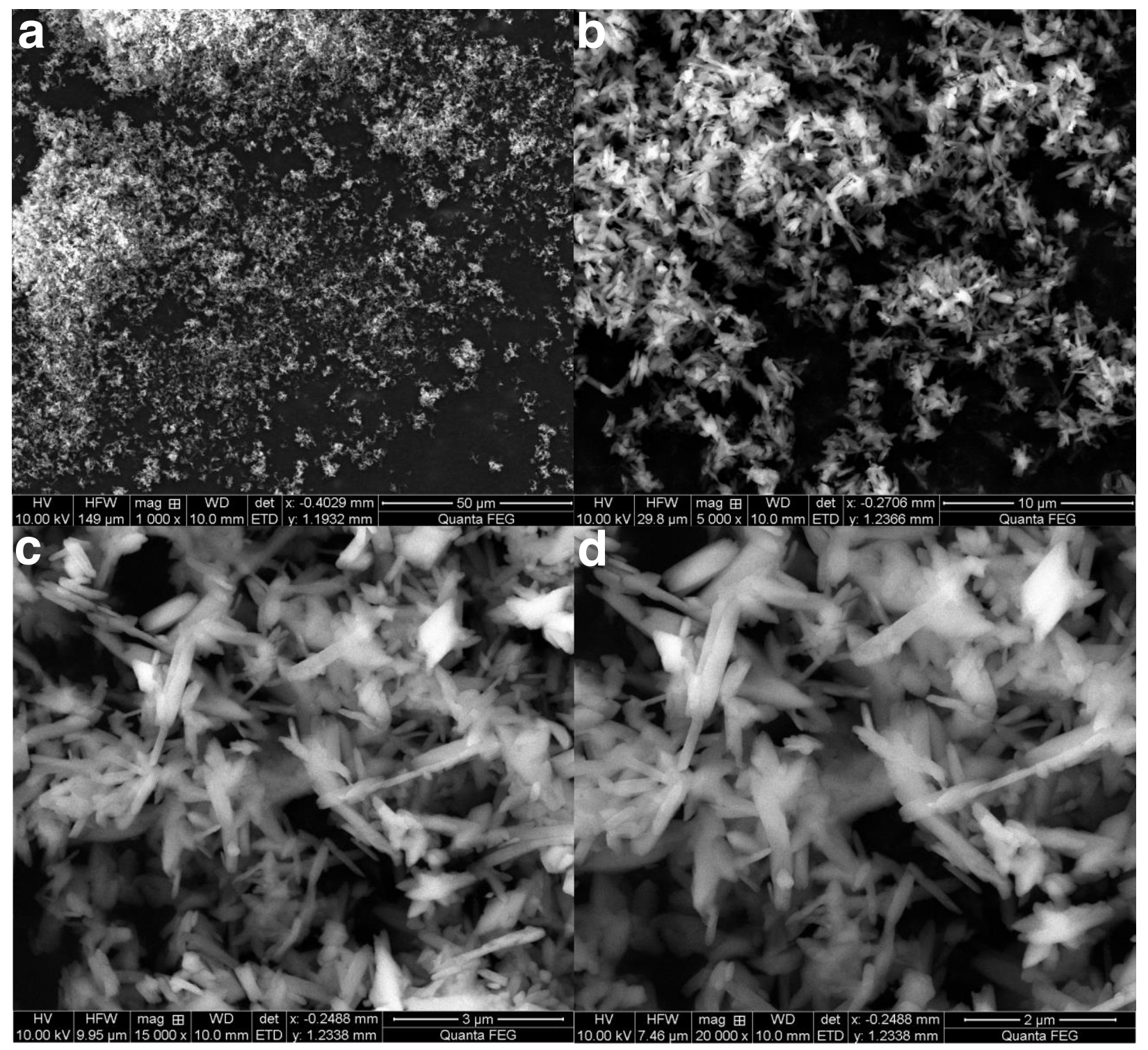

Figure S1. White powder of synthesized MIL-53(Al) was placed on top of carbon tape that was attached to a disposable SEM stage. Several SEM images of the synthesized MIL-53(Al) were taken at different magnifications. (a.) 1000x (b.) 5000x (c.) 15000x (d.) 20000x. These SEM images showed that the synthesized MIL-53(Al) is a crystalline white powder with around $1 \mu \mathrm{m}$ long needle-like crystals. 


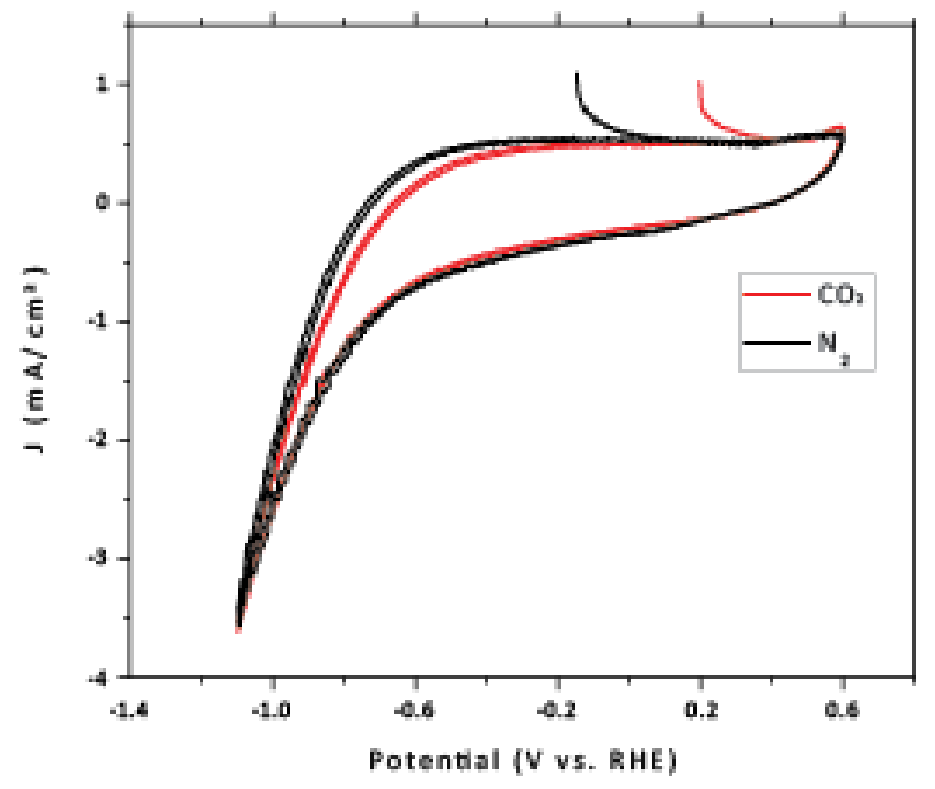

Figure S2. Using two-compartment flow cell electrochemical setup, the electrolyte solution in the working compartment was sparged for 10 minutes with $\mathrm{N}_{2}$ or $\mathrm{CO}_{2}$. Cyclic voltammetry (CV) scans were then taken from 0.6 to $-1.1 \mathrm{~V}$ vs RHE with $10 \mathrm{mV} / \mathrm{s}$ scan rate. $\mathrm{CV}$ scans were performed for working electrode in two different atmosphere: $\mathrm{CO}_{2}$ atmosphere (red curve) and $\mathrm{N}_{2}$ atmosphere (black curve). These $\mathrm{CV}$ scans showed that the working electrodes containing MIL-53(Al) were active in $\mathrm{CO}_{2}$ and $\mathrm{N}_{2}$ atmosphere. Under $\mathrm{N}_{2}$ atmosphere, working electrodes undergo hydrogen evolution reaction (HER), similar to metallic $\mathrm{Al}$ that is only active for $\mathrm{HER}^{5}$. 
Cathode

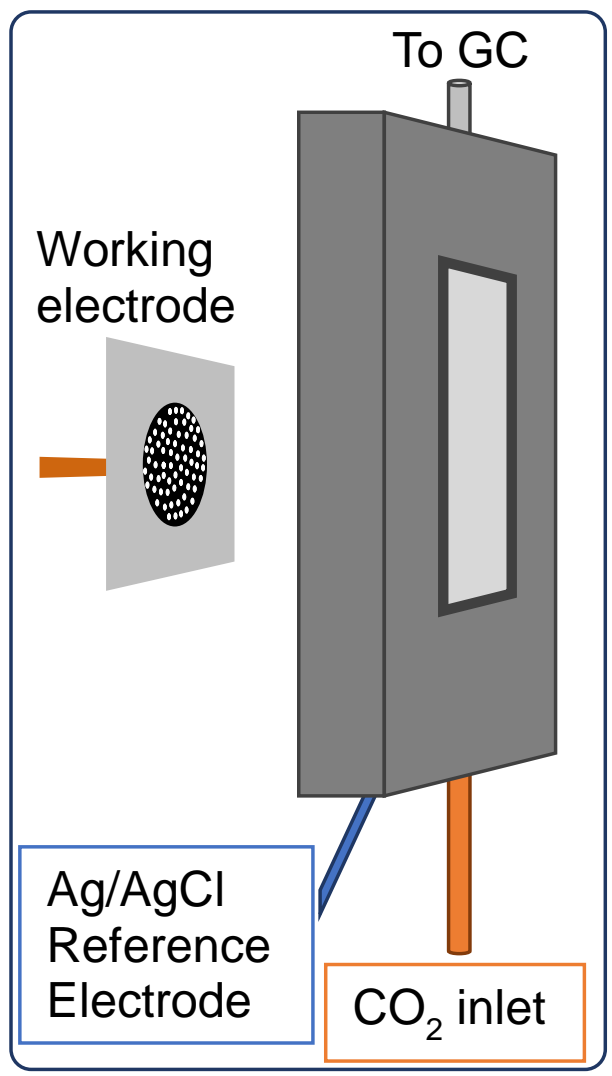

\section{Anode}

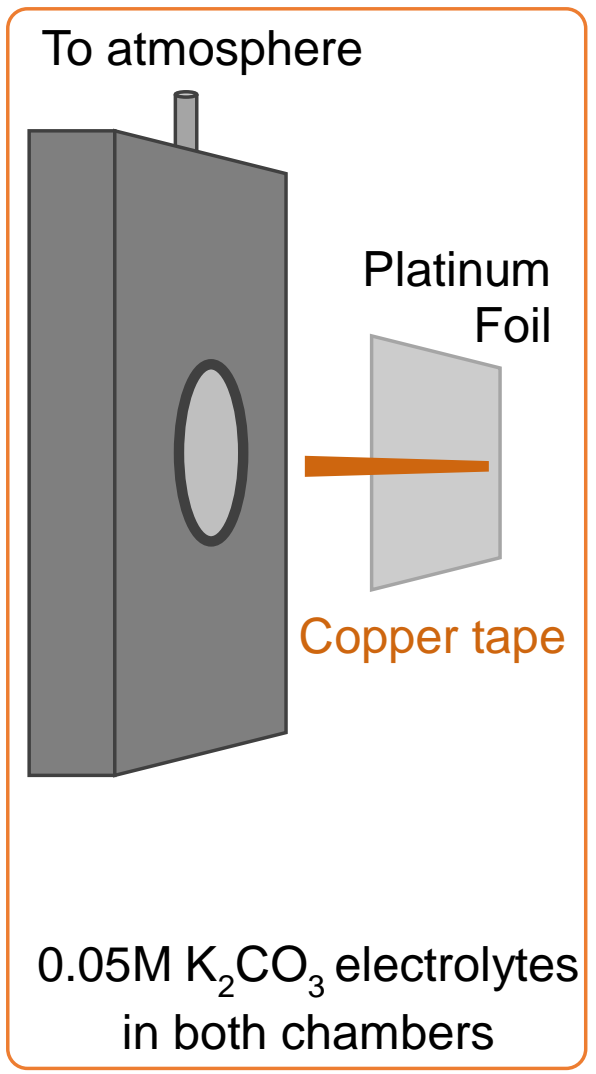

Figure S3. Two-compartment flow cell used for electroreduction of carbon dioxide.

Table S1. Fabricated working electrode containing MIL-53(Al) under $\mathrm{N}_{2}$ atmosphere. Control experiments were performed for 65 minutes $\mathrm{CA}$ at a constant applied potential. There is only hydrogen production detected.

\begin{tabular}{|c|c|c|c|c|c|c|}
\hline \multirow{2}{*}{$\begin{array}{c}\text { Potential vs } \\
\text { RHE (V) }\end{array}$} & \multicolumn{6}{|c|}{ Faradaic Efficiency } \\
\cline { 2 - 7 } & Hydrogen & CO & Methane & Ethane & Ethylene & Formic Acid \\
\hline-1.0 & $85.7 \%$ & $0 \%$ & $0 \%$ & $0 \%$ & $0 \%$ & $0 \%$ \\
\hline
\end{tabular}

Table S2. Background: plain carbon paper under $\mathrm{CO}_{2}$ atmosphere. Control experiments were performed under the same condition for electrochemical reduction of $\mathrm{CO}_{2}$ for the reported product detection, 65 minutes $\mathrm{CA}$ at a constant applied potential. There is no $\mathrm{CO}_{2} \mathrm{R}$ product detected.

\begin{tabular}{|c|c|c|c|c|c|c|}
\hline \multirow{2}{*}{$\begin{array}{c}\text { Potential vs } \\
\text { RHE (V) }\end{array}$} & \multicolumn{6}{|c|}{ Faradaic Efficiency } \\
\cline { 2 - 7 } & Hydrogen & CO & Methane & Ethane & Ethylene & Formic Acid \\
\hline-1.0 & $42.0 \%$ & $0 \%$ & $0 \%$ & $0 \%$ & $0 \%$ & $0 \%$ \\
\hline
\end{tabular}


Table S3. Background: plain carbon paper and Nafion $(0.17 \mu \mathrm{L})$ under $\mathrm{CO}_{2}$ atmosphere. Control experiments were performed under the same condition for electrochemical reduction of $\mathrm{CO}_{2}$ for the reported product detection, 65 minutes $\mathrm{CA}$ at a constant applied potential. There is negligible $\mathrm{CO}_{2} \mathrm{R}$ product detected.

\begin{tabular}{|c|c|c|c|c|c|c|}
\hline \multirow{2}{*}{$\begin{array}{c}\text { Potential vs } \\
\text { RHE (V) }\end{array}$} & \multicolumn{6}{|c|}{ Faradaic Efficiency } \\
\cline { 2 - 7 } & Hydrogen & CO & Methane & Ethane & Ethylene & Formic Acid \\
\hline-1.0 & $45.8 \%$ & $0.93 \%$ & $0 \%$ & $0 \%$ & $0 \%$ & $0 \%$ \\
\hline
\end{tabular}
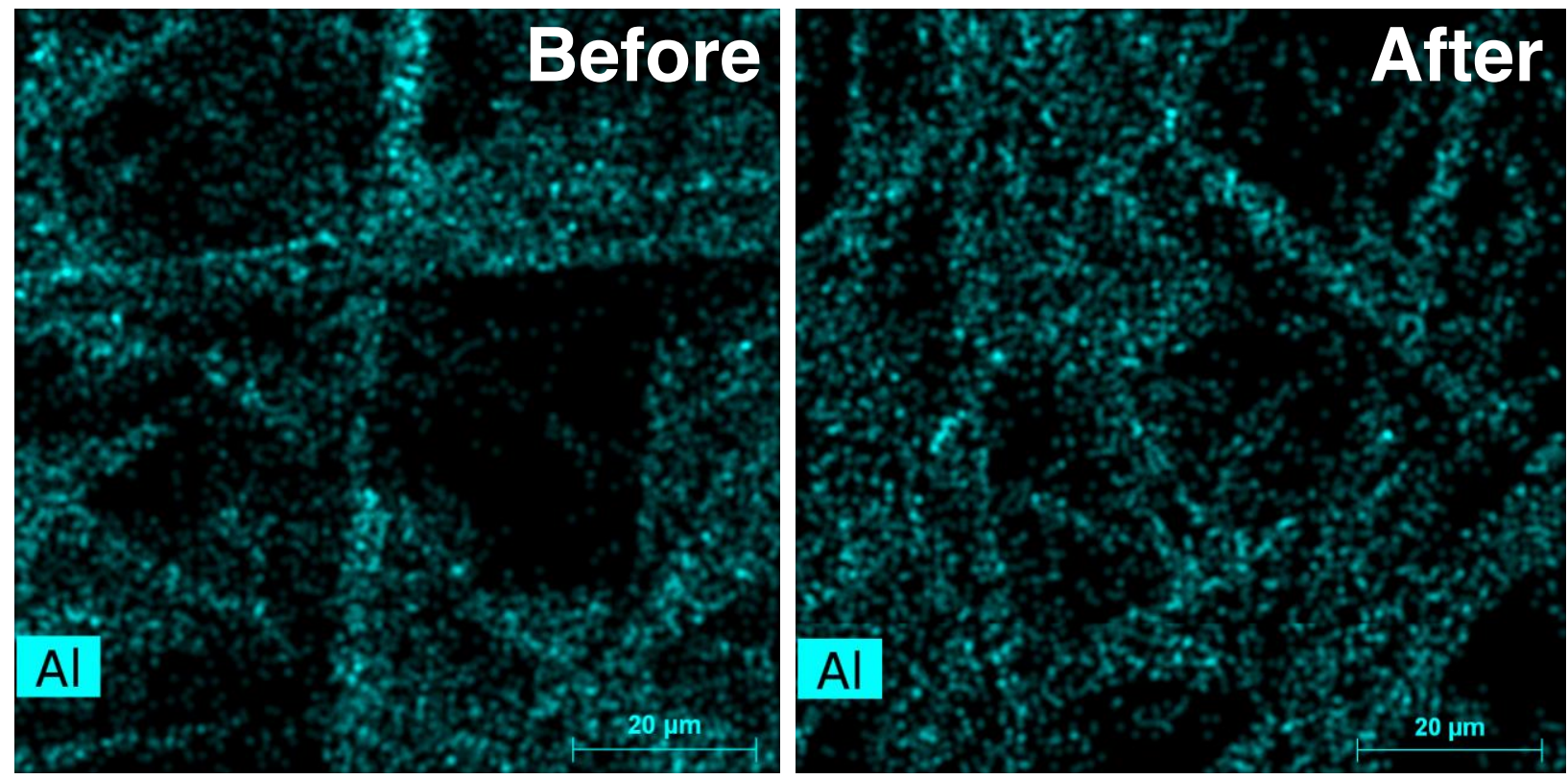

Figure S4. Scanning electron microscopes-energy-dispersive X-Ray (SEM-EDX) of Al of the surface of the working electrodes before and after 4 hours 30 minutes electrochemical testing at five different potentials $(-1.1 \mathrm{~V},-1.0 \mathrm{~V},-0.9 \mathrm{~V},-0.8 \mathrm{~V}$, and $-0.7 \mathrm{~V}$ vs RHE) to ensure the presence of the elemental components of MIL-53(Al) on the surface of working electrodes. The SEM-EDX map of the electrode before electrochemical testing (left) showed that MIL-53(Al) is evenly distributed by the presence of Al(blue) evenly distributed on the electrode. For the sake of clarity, we did not include carbon in the reported SEM-EDX maps, since there is a strong carbon signal coming from the carbon paper support in addition to the MOF's organic linker. The SEM-EDX map of the electrode after electrochemical testing (right) showed that $\mathrm{Al}$ (blue) was still evenly distributed on the surface of the electrode, supporting that MIL-53(Al) is relatively stable under the operating condition. 
Table S4. Initial screening of $\mathrm{CO}_{2} \mathrm{R}$ at applied potentials of $-0.7 \mathrm{~V}$ vs RHE and $-0.8 \mathrm{~V}$ vs RHE.

\begin{tabular}{|c|c|c|c|c|}
\hline \multirow{2}{*}{$\begin{array}{c}\text { Potential vs RHE } \\
(\mathrm{V})\end{array}$} & \multirow{2}{*}{ Current (mA) } & CO & Formic Acid & Hydrogen \\
\cline { 3 - 5 } & & $3 \%$ & $0 \%$ & $53 \%$ \\
\hline-0.7 & 0.18 & $3 \%$ & $7 \%$ & $64 \%$ \\
\hline-0.8 & 0.70 & & \\
\hline
\end{tabular}

Table S5. Faradaic efficiency of MIL-53(Al) catalyzed $\mathrm{CO}_{2}$ reduction at different applied potentials.

\begin{tabular}{|c|c|c|c|c|}
\hline \multirow{2}{*}{$\begin{array}{c}\text { Potential vs RHE } \\
(\mathrm{V})\end{array}$} & \multirow{2}{*}{ Current (mA) } & \multicolumn{3}{|c|}{ Faradic Efficiency } \\
\cline { 3 - 5 } & & $\mathrm{CO}$ & Formic Acid & Hydrogen \\
\hline-0.9 & 1.12 & $7 \%$ & $12 \%$ & $84 \%$ \\
\hline-0.9 & 1.34 & $9 \%$ & $16 \%$ & $80 \%$ \\
\hline-1.0 & 2.43 & $12 \%$ & $16 \%$ & $75 \%$ \\
\hline-1.0 & 1.87 & $13 \%$ & $22 \%$ & $71 \%$ \\
\hline-1.1 & 4.52 & $15 \%$ & $20 \%$ & $68 \%$ \\
\hline-1.1 & 3.09 & $26 \%$ & $17 \%$ & $63 \%$ \\
\hline
\end{tabular}

Table S6. Average and error analysis of faradaic efficiency of MIL-53(Al) catalyzed $\mathrm{CO}_{2}$ reduction at different applied potentials.

\begin{tabular}{|c|c|c|c|c|c|c|c|c|c|}
\hline \multirow{2}{*}{$\begin{array}{c}\text { Potential } \\
\text { vs RHE } \\
\text { (V) }\end{array}$} & \multicolumn{4}{|c|}{ Average Faradaic Efficiency } & \multicolumn{3}{c|}{ Standard Deviation } & \multicolumn{3}{c|}{ Standard Error Mean (SEM) } \\
\cline { 2 - 10 } & CO & Formic Acid & Hydrogen & CO & $\begin{array}{c}\text { Formic } \\
\text { Acid }\end{array}$ & Hydrogen & CO & $\begin{array}{c}\text { Formic } \\
\text { Acid }\end{array}$ & Hydrogen \\
\hline-0.9 & $8 \%$ & $14 \%$ & $82 \%$ & $1 \%$ & $3 \%$ & $6 \%$ & $1 \%$ & $2 \%$ & $4 \%$ \\
\hline-1.0 & $13 \%$ & $19 \%$ & $73 \%$ & $1 \%$ & $4 \%$ & $6 \%$ & $1 \%$ & $3 \%$ & $4 \%$ \\
\hline-1.1 & $21 \%$ & $19 \%$ & $66 \%$ & $8 \%$ & $2 \%$ & $7 \%$ & $6 \%$ & $2 \%$ & $5 \%$ \\
\hline
\end{tabular}


Table S7. Activity and selectivity of Molecular Organic Frameworks as $\mathrm{CO}_{2} \mathrm{R}$ electrocatalysts.

\begin{tabular}{|c|c|c|c|c|c|}
\hline Electrocatalyst & $\begin{array}{c}\text { Applied } \\
\text { Potential } \\
\text { (V vs } \\
\text { RHE) }\end{array}$ & Electrolyte & $\begin{array}{c}\mathrm{CO}_{2} \mathrm{R} \\
\text { products } \\
(\% \mathrm{FE})\end{array}$ & TOF $\left(\mathrm{h}^{-1}\right)$ & Reference \\
\hline MIL-53(Al) & -0.9 & $0.05 \mathrm{M} \mathrm{K}_{2} \mathrm{CO}_{3}$ & $22 \%^{\mathrm{a}}$ & 34 & This study \\
\hline MIL-53(Al) & -1.0 & $0.05 \mathrm{M} \mathrm{K}_{2} \mathrm{CO}_{3}$ & $32 \%^{\mathrm{a}}$ & 84 & This study \\
\hline MIL-53(Al) & -1.1 & $0.05 \mathrm{M} \mathrm{K}_{2} \mathrm{CO}_{3}$ & $40 \%^{\mathrm{a}}$ & 182 & This study \\
\hline COF-367-Co & -0.67 & $0.5 \mathrm{M} \mathrm{KHCO}_{3}$ & $91 \%^{\mathrm{b}}$ & 165 & 8 \\
\hline $\begin{array}{c}\left.\mathrm{Al}_{2}(\mathrm{OH})_{2} \mathrm{TCPP}-\mathrm{Co}\right] \\
\text { MOF }\end{array}$ & -0.7 & $0.5 \mathrm{M} \mathrm{K}_{2} \mathrm{CO}_{3}$ & $76 \%{ }^{\mathrm{b}}$ & $\sim 200$ & 9 \\
\hline \multicolumn{7}{|l}{$\mathrm{CO}_{2} \mathrm{R}$ products composed of CO and formic acid. ${ }^{\mathrm{b}} \mathrm{CO}_{2} \mathrm{R}$ products composed of only CO. } \\
\hline
\end{tabular}

Table S8. Activity and selectivity of MIL-53(Al) compared to $\mathrm{Al}$ foil as $\mathrm{CO}_{2} \mathrm{R}$ electrocatalysts.

\begin{tabular}{|c|c|c|c|c|c|}
\hline Electrocatalyst & $\begin{array}{c}\text { Applied } \\
\text { Potential (V vs } \\
\text { RHE) }\end{array}$ & Electrolyte & $\begin{array}{c}\mathrm{CO}_{2} \mathrm{R} \\
\text { products } \\
(\% \mathrm{FE})\end{array}$ & $\begin{array}{c}\text { Partial Current } \\
\text { Densities toward } \\
\mathrm{CO}_{2} \mathrm{R}\left(\mathrm{mA} / \mathrm{cm}^{2}\right)\end{array}$ & Reference \\
\hline MIL-53(Al) & -0.9 & $\begin{array}{c}0.05 \mathrm{M} \mathrm{K}_{2} \mathrm{CO}_{3} \\
(\mathrm{pH}=6.8)\end{array}$ & $22 \%^{\mathrm{a}}$ & 0.22 & This study \\
\hline MIL-53(Al) & -1.0 & $\begin{array}{c}0.05 \mathrm{M} \mathrm{K}_{2} \mathrm{CO}_{3} \\
(\mathrm{pH}=6.8)\end{array}$ & $32 \%^{\mathrm{a}}$ & 0.54 & This study \\
\hline MIL-53(Al) & -1.1 & $\begin{array}{c}0.05 \mathrm{M} \mathrm{K}_{2} \mathrm{CO}_{3} \\
(\mathrm{pH}=6.8)\end{array}$ & $40 \%^{\mathrm{a}}$ & 1.2 & This study \\
\hline $\mathrm{Al}$ foil & -1.0 & $\begin{array}{c}0.1 \mathrm{M} \mathrm{KHCO} \\
(\mathrm{pH}=6.6)\end{array}$ & $1 \%{ }^{\mathrm{b}}$ & 0.008 & 10 \\
\hline${ }^{\mathrm{a}} \mathrm{CO}_{2} \mathrm{R}$ products composed of $\mathrm{CO}$ and formic acid. ${ }^{\mathrm{b}} \mathrm{CO}_{2} \mathrm{R}$ products composed of methane, ethylene, \\
and ethane.
\end{tabular}
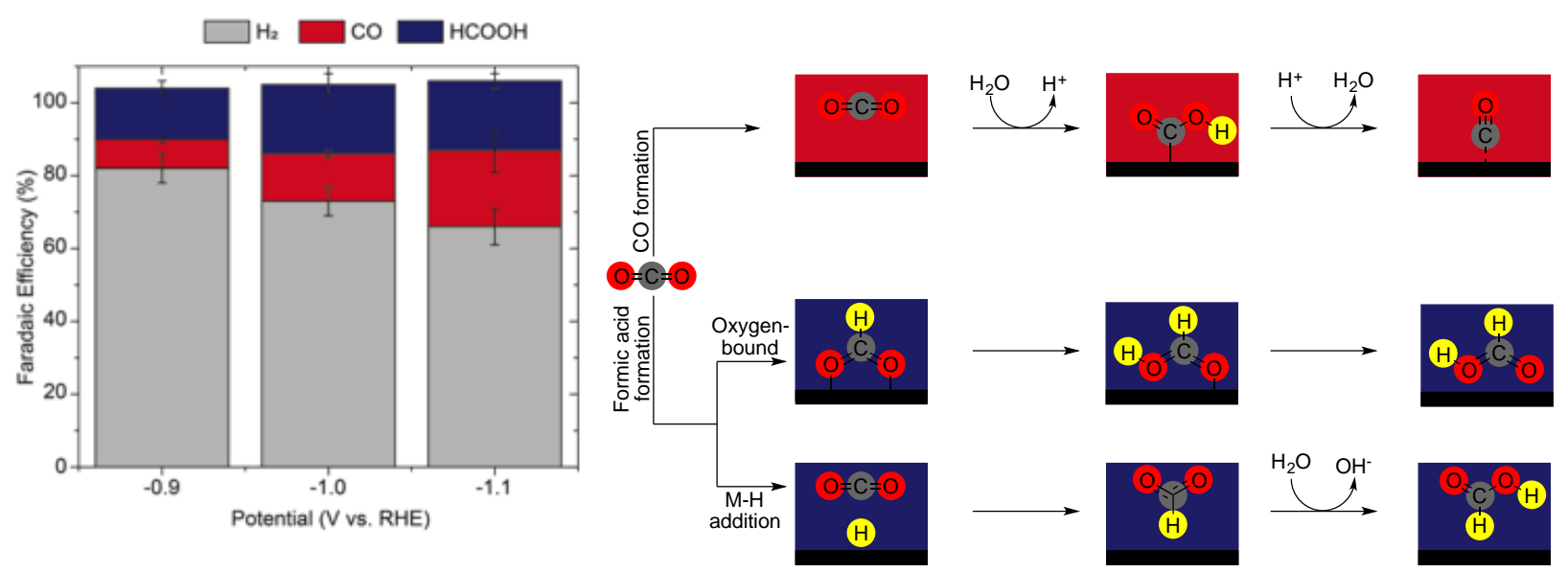

Figure S5. Mechanism of $\mathrm{CO}_{2}$ reduction through two different pathways: carbon-bound pathway leads to $\mathrm{CO}$ formation and oxygen-bound pathway or direct addition of $\mathrm{CO}_{2}$ to a surface metal-hydride lead to formic acid formation. ${ }^{7,11}$ 
Table S9. Faradaic efficiency of $\mathrm{Al}(\mathrm{OH})_{3}$ catalyzed $\mathrm{CO}_{2}$ reduction at different applied potentials.

\begin{tabular}{|c|c|c|c|c|}
\hline \multirow{2}{*}{ Potential vs RHE $(\mathrm{V})$} & \multirow{2}{*}{ Current $(\mathrm{mA})$} & \multicolumn{3}{|c|}{ Faradic Efficiency } \\
\cline { 3 - 5 } & & Hydrogen & CO & Formic Acid \\
\hline-0.9 & 0.52 & $9.52 \%$ & $0 \%$ & $0 \%$ \\
\hline-0.9 & 0.36 & $24.70 \%$ & $0 \%$ & $0 \%$ \\
\hline-1.0 & 0.79 & $40.21 \%$ & $0 \%$ & $16.75 \%$ \\
\hline-1.0 & 0.78 & $43.86 \%$ & $0 \%$ & $18.39 \%$ \\
\hline-1.1 & 1.33 & $44.63 \%$ & $1.97 \%$ & $23.46 \%$ \\
\hline-1.1 & 1.32 & $48.76 \%$ & $3.97 \%$ & $27.79 \%$ \\
\hline
\end{tabular}

Table S10. Average and error analysis of faradaic efficiency of $\mathrm{Al}(\mathrm{OH})_{3}$ catalyzed $\mathrm{CO}_{2}$ reduction at different applied potentials.

\begin{tabular}{|c|c|c|c|c|c|c|c|c|c|}
\hline \multirow{2}{*}{ Potential vs RHE (V) } & \multicolumn{3}{|c|}{ Average Faradaic Efficiency } & \multicolumn{3}{|c|}{ Standard Deviation } & \multicolumn{3}{|c|}{ Standard Error Mean (SEM) } \\
\hline & $\mathrm{CO}$ & Formic Acid & Hydrogen & $\mathrm{CO}$ & Formic Acid & Hydrogen & $\mathrm{CO}$ & Formic Acid & Hydrogen \\
\hline-0.9 & $0 \%$ & $0 \%$ & $17 \%$ & $0 \%$ & $0 \%$ & $11 \%$ & $0 \%$ & $0 \%$ & $8 \%$ \\
\hline-1.0 & $0 \%$ & $18 \%$ & $42 \%$ & $0 \%$ & $1 \%$ & $3 \%$ & $0 \%$ & $1 \%$ & $2 \%$ \\
\hline-1.1 & $3 \%$ & $26 \%$ & $47 \%$ & $1 \%$ & $3 \%$ & $3 \%$ & $1 \%$ & $2 \%$ & $2 \%$ \\
\hline
\end{tabular}
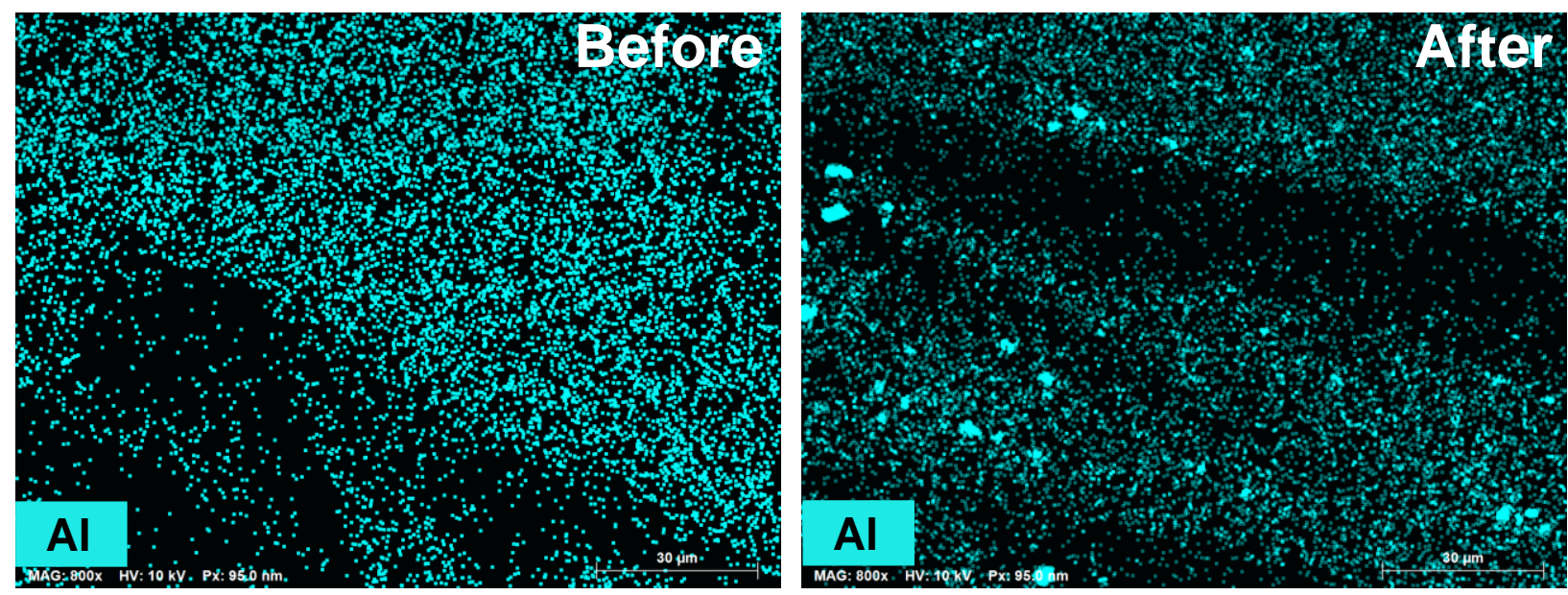

Figure S6. Scanning electron microscopes-energy-dispersive X-Ray (SEM-EDX) of Al of the surface of the working electrodes before and after 3 hours and 15 minutes electrochemical testing at three different potentials $(-1.1 \mathrm{~V},-1.0 \mathrm{~V}$, and $-0.9 \mathrm{~V}$ vs. RHE) to ensure the presence of the elemental components of $\mathrm{Al}(\mathrm{OH})_{3}$ on the surface of working electrodes. The SEM-EDX map of the electrode before electrochemical testing (left) showed that $\mathrm{Al}(\mathrm{OH})_{3}$ is evenly distributed by the presence of $\mathrm{Al}(\mathrm{blue})$ evenly distributed on the electrode. The SEM-EDX map of the electrode after electrochemical testing (right) showed that Al (blue) was still evenly distributed on the surface of the electrode, supporting that $\mathrm{Al}(\mathrm{OH})_{3}$ is relatively stable under the operating condition.

Table S11. Turnover frequency (TOF) calculation based on faradaic efficiency and current using: 
$T O F=\frac{Q * F E}{t * N * F * n c a t a l y s t}=\frac{i * F E}{N * F * n c a t a l y s t}$,

where $\mathrm{Q}$ is the total charge passed in time $\mathrm{t}$, $\mathrm{i}$ is the current, $\mathrm{FE}$ is the Faradaic efficiency for the desired product, $\mathrm{N}$ is the number of electrons in the half reaction $\left(\mathrm{N}=2\right.$ for $\mathrm{CO}_{2}$ to $\mathrm{CO}$ or $\mathrm{HCO}_{2} \mathrm{H}$ conversion), $\mathrm{F}$ is the Faraday constant ( $\mathrm{F}=96485 \mathrm{C} / \mathrm{mol}$ electrons), and $\mathrm{n}_{\text {catalyst }}$ is the mole of MIL-53(Al)/unit cell deposited onto active area of $\mathrm{CP}$.

TOF for $\mathrm{CO}$ and Formic Acid

\begin{tabular}{|c|c|c|c|c|c|c|c|c|c|}
\hline \multirow[b]{2}{*}{$\begin{array}{c}\text { Potential } \\
\text { vs RHE } \\
\text { (V) }\end{array}$} & \multicolumn{4}{|c|}{ Run 1} & \multicolumn{4}{|c|}{ Run 2} & \multirow[b]{2}{*}{$\begin{array}{c}\text { Average } \\
\text { TOF } \\
\left(\mathrm{h}^{-1}\right)\end{array}$} \\
\hline & $\begin{array}{c}\text { Current } \\
(\mathrm{mA})\end{array}$ & $\begin{array}{l}\mathrm{FE} \text { for } \mathrm{CO} \\
\text { and formic } \\
\text { acid }\end{array}$ & $\begin{array}{l}\text { TOF } \\
\left(\mathrm{s}^{-1}\right)\end{array}$ & $\begin{array}{l}\text { TOF } \\
\left(\mathrm{h}^{-1}\right)\end{array}$ & $\begin{array}{c}\text { Current } \\
(\mathrm{mA})\end{array}$ & $\begin{array}{l}\text { FE for } \mathrm{CO} \\
\text { and formic } \\
\text { acid }\end{array}$ & $\begin{array}{l}\text { TOF } \\
\left(\mathrm{s}^{-1}\right)\end{array}$ & $\begin{array}{l}\text { TOF } \\
\left(\mathrm{h}^{-1}\right)\end{array}$ & \\
\hline-0.9 & 1.12 & 0.19 & 0.007 & 27 & 1.34 & 0.25 & 0.012 & 42 & 34 \\
\hline-1 & 2.43 & 0.28 & 0.024 & 85 & 1.87 & 0.35 & 0.023 & 82 & 84 \\
\hline-1.1 & 4.52 & 0.35 & 0.055 & 198 & 3.09 & 0.43 & 0.046 & 166 & 182 \\
\hline
\end{tabular}

TOF for $\mathrm{CO}$

\begin{tabular}{|c|c|c|c|c|c|c|c|c|c|}
\hline \multirow{2}{*}{$\begin{array}{l}\text { Potential } \\
\text { vs RHE } \\
\text { (V) }\end{array}$} & \multicolumn{4}{|c|}{ Run 1} & \multicolumn{4}{|c|}{ Run 2} & \multirow{2}{*}{$\begin{array}{c}\text { Average } \\
\text { TOF } \\
\left(\mathrm{h}^{-1}\right) \\
\end{array}$} \\
\hline & $\begin{array}{c}\text { Current } \\
(\mathrm{mA})\end{array}$ & $\mathrm{FE}$ for $\mathrm{CO}$ & $\begin{array}{l}\text { TOF } \\
\left(\mathrm{s}^{-1}\right) \\
\end{array}$ & $\begin{array}{l}\text { TOF } \\
\left(\mathrm{h}^{-1}\right)\end{array}$ & $\begin{array}{c}\text { Current } \\
(\mathrm{mA})\end{array}$ & $\mathrm{FE}$ for $\mathrm{CO}$ & $\begin{array}{l}\text { TOF } \\
\left(\mathrm{s}^{-1}\right)\end{array}$ & $\begin{array}{l}\text { TOF } \\
\left(\mathrm{h}^{-1}\right)\end{array}$ & \\
\hline-0.9 & 1.12 & 0.07 & 0.003 & 10 & 1.34 & 0.09 & 0.004 & 15 & 12 \\
\hline-1 & 2.43 & 0.12 & 0.01 & 37 & 1.87 & 0.13 & 0.008 & 30 & 33 \\
\hline-1.1 & 4.52 & 0.15 & 0.024 & 85 & 3.09 & 0.26 & 0.028 & 101 & 93 \\
\hline
\end{tabular}

TOF for Formic Acid

\begin{tabular}{|c|c|c|c|c|c|c|c|c|c|}
\hline \multirow{2}{*}{$\begin{array}{c}\text { Potential } \\
\text { vs RHE } \\
\text { (V) }\end{array}$} & \multicolumn{4}{|c|}{ Run 1} & \multicolumn{4}{|c|}{ Run 2} & \multirow{2}{*}{$\begin{array}{c}\text { Average } \\
\text { TOF } \\
\left(\mathrm{h}^{-1}\right) \\
\end{array}$} \\
\hline & $\begin{array}{l}\text { Current } \\
(\mathrm{mA})\end{array}$ & $\begin{array}{l}\text { FE for formic } \\
\text { acid }\end{array}$ & $\begin{array}{l}\text { TOF } \\
\left(\mathrm{s}^{-1}\right)\end{array}$ & $\begin{array}{l}\text { TOF } \\
\left(\mathrm{h}^{-1}\right)\end{array}$ & $\begin{array}{l}\text { Current } \\
(\mathrm{mA})\end{array}$ & $\begin{array}{l}\text { FE for formic } \\
\text { acid }\end{array}$ & $\begin{array}{l}\text { TOF } \\
\left(\mathrm{s}^{-1}\right)\end{array}$ & $\begin{array}{l}\text { TOF } \\
\left(\mathrm{h}^{-1}\right)\end{array}$ & \\
\hline-0.9 & 1.12 & 0.12 & 0.005 & 17 & 1.34 & 0.16 & 0.007 & 27 & 22 \\
\hline-1 & 2.43 & 0.16 & 0.014 & 49 & 1.87 & 0.22 & 0.014 & 52 & 50 \\
\hline-1.1 & 4.52 & 0.2 & 0.031 & 113 & 3.09 & 0.17 & 0.018 & 66 & 89 \\
\hline
\end{tabular}

TOF for Hydrogen

\begin{tabular}{|c|c|c|c|c|c|c|c|c|c|}
\hline \multirow{2}{*}{$\begin{array}{l}\text { Potential } \\
\text { vs RHE } \\
\text { (V) }\end{array}$} & \multicolumn{4}{|c|}{ Run 1} & \multicolumn{4}{|c|}{ Run 2} & \multirow{2}{*}{$\begin{array}{c}\text { Average } \\
\text { TOF } \\
\left(\mathrm{h}^{-1}\right)\end{array}$} \\
\hline & $\begin{array}{c}\text { Current } \\
(\mathrm{mA})\end{array}$ & $\begin{array}{c}\text { FE for } \\
\text { hydrogen }\end{array}$ & $\begin{array}{l}\text { TOF } \\
\left(\mathrm{s}^{-1}\right)\end{array}$ & $\begin{array}{l}\text { TOF } \\
\left(h^{-1}\right)\end{array}$ & $\begin{array}{c}\text { Current } \\
(\mathrm{mA})\end{array}$ & $\begin{array}{c}\text { FE for } \\
\text { hydrogen }\end{array}$ & $\begin{array}{l}\text { TOF } \\
\left(\mathrm{s}^{-1}\right)\end{array}$ & $\begin{array}{l}\text { TOF } \\
\left(\mathrm{h}^{-1}\right)\end{array}$ & \\
\hline-0.9 & 1.12 & 0.84 & 0.033 & 118 & 1.34 & 0.8 & 0.037 & 134 & 126 \\
\hline-1 & 2.43 & 0.75 & 0.063 & 228 & 1.87 & 0.71 & 0.046 & 166 & 197 \\
\hline-1.1 & 4.52 & 0.63 & 0.099 & 357 & 3.09 & 0.68 & 0.073 & 263 & 310 \\
\hline
\end{tabular}




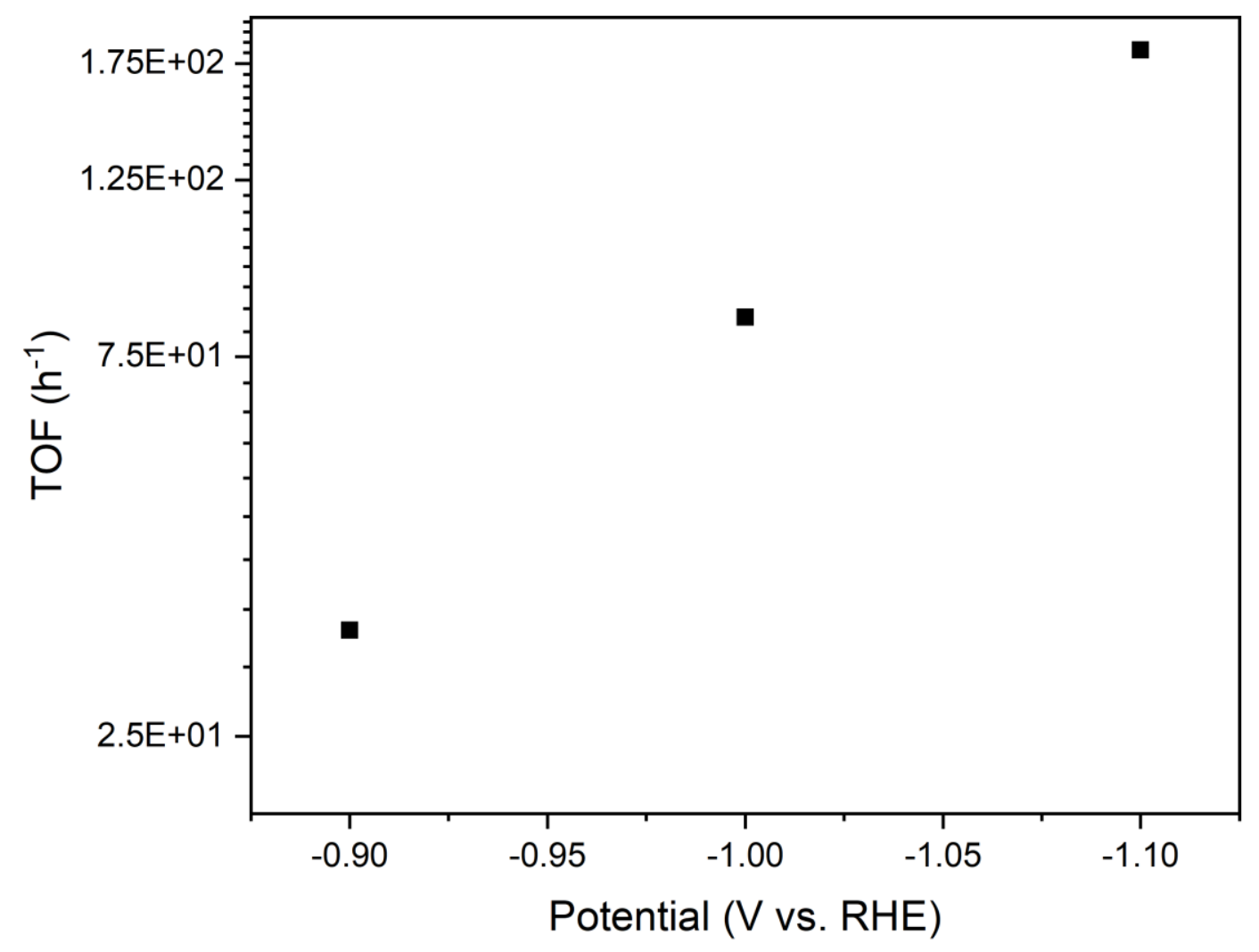

Figure S7. Exponential relationship between applied potential (V vs RHE) and turnover frequency (TOF) for carbon-based products. 


\section{References}

1. Ahnfeldt, T.; Gunzelmann, D.; Loiseau, T.; Hirsemann, D.; Senker, J.; Férey, G.; Stock, N. Synthesis and Modification of a Functionalized 3D Open-Framework Structure with MIL-53 Topology. Inorg. Chem. 2009, 48, 3057-3064.

2. Loiseau, T.; Sere, C.; Huguenard, C.; Fink, G.; Taulelle, F.; Henry, M.; Bataille, T.; Ferey, G. A. A Rationale for the Large Breathing of the Porous Aluminum Terephthalate (MIL53) Upon Hydration. Chem. Eur. J. 2004, 10, 1373-1382.

3. Jung, S.; McCory, C. C.; Ferrer, I. M.; Peters, J. C.; Jaramillo, T. F. Benchmarking nanoparticulate metal oxide electrocatalysts for the alkaline water oxidation reaction. $J$. Mater. Chem. A, 2016, 4, 3068-3076.

4. Lobaccaro, P.; Singh, M. R.; Clark, E. L.; Kwon, Y.; Bell, A. T.; Ager, J. W. Effects of the temperature and gas-liquid mass transfer on the operation of small electrochemical cell for the quantitative evaluation of $\mathrm{CO}_{2}$ reduction electrocatalysts. Phys. Chem. Chem. Phys. 2016, $18,26777-26785$.

5. Hori, Y. in Modern Aspects of Electrochemistry Vol. 42, CH. 3 (eds Vayenas, C. G., White, R. E., \& Gamboa-Aldeco, M. E.) 89-189 (Springer, New York, 2008).

6. Lum, Y.; Kwon, Y.; Lobaccaro, P.; Chen, L.; Clark, E. L.; Bell, A. T.; Ager, J. W. Trace Levels of Copper in Carbon Materials Show Significant Electrochemical $\mathrm{CO}_{2}$ Reduction Activity. ACS Catal. 2016, 6, 202-209.

7. Feaster, J. T.; Shi, C.; Cave, E. R.; Hatuskade, T.; Abram, D. N.; Kuhl, K. P.; Hahn, C. Norskov, J. K.; Jaramillo, T. F. Understanding Selectivity for the Electrochemical 
Reduction of Carbon Dioxide to Formic Acid and Carbon Monoxide on Metal Electrodes. ACS Catal. 2017, 7, 4822-4827.

8. Lin, S.; Diercks, C. S.; Zhang, Y. -B.; Kornienko, N.; Nichols, E. M.; Zhao, Y.; Paris, D. Kim, A. R.; Yang, P.; Yaghi, O. M.; Chang, C. J. Covalent organic frameworks comprising cobalt porphyrins for catalytic $\mathrm{CO}_{2}$ reduction in water. Science. 2015, 349, 1208-1213.

9. Kornienko, N.; Zhao, Y.; Kley, C. S.; Zhu, C.; Kim, D.; Lin, S.; Chang, C. J.; Yaghi, O. M.; Yang, P. Metal-Organic Frameworks for Electrocatalytic Reduction of Carbon Dioxide. J. Am. Chem. Soc. 2015, 137, 14129-14135.

10. Noda, H.; Ikeda, S.; Oda, Y.; Imai, K.; Maeda, M.; Ito, K. Electrochemical Reduction of Carbon Dioxide at Various Metal Electrodes in Aqueous Potassium Hydrogen Carbonate Solution. Bull. Chem. Soc. Jpn. 1990, 63, 2459-2462.

11. Cheng, T.; Xiao, H.; Goddard, W. A. Reaction Mechanism for the Electrochemical Reduction of $\mathrm{CO}_{2}$ to $\mathrm{CO}$ and Formate on the $\mathrm{Cu}(100)$ Surface at $298 \mathrm{~K}$ from Quantum Mechanics Free Energy Calculations with Explicit Water. J. Am. Chem. Soc. 2016, 138, $13802-13805$ 